\title{
Modele uprawiania socjologii w ujęciu Michaela Burawoya a rola socjologa w społeczeństwie
}

Adam Kosznicki | Wydział Nauk Społecznych, Uniwersytet Gdańsk

\section{Streszczenie}

Słowa kluczowe:

socjologia

publiczna,

Michael Burawoy,

Piotr Sztompka,

Stanisław Ossowski,

Michał Hułas,

Rangvald Kallenberg,

rola społeczna

badacza

Celem niniejszego artykułu jest prezentacja nowego nurtu w dyskursie socjologicznym, jakim jest socjologia publiczna. Jej twórcą jest amerykański badacz Michael Burawoy. Od czasu pierwszego wygłoszenia jego tez dotyczących roli socjologii i osób ją uprawiających w nowoczesnym społeczeństwie socjologia publiczna spotkała się z bardzo dużym rozgłosem oraz skrajnie różnymi ocenami. Podczas gdy jedni traktowali ją jako nową doktrynę dla badaczy społecznych, drudzy odmawiali jej jakiejkolwiek wartości. Jednym z głównych krytyków tego podejścia w Polsce jest Piotr Sztompka. Jego argumentom przeciw socjologii publicznej poświęcona jest druga część artykułu. Poza tym przytoczone zostaną stanowiska innych oponentów Burawoya. Podsumowaniem tego tekstu jest opinia własna autora dotycząca socjologii publicznej oraz tego, jaka powinna być rola socjologów we współczesnym społeczeństwie.

\section{Models of Sociology by M. Burawoy and the Role of the Sociologist in Society}

\section{Abstract}

Keywords: public sociology, Michael Burawoy,

Piotr Sztompka, Stanisław Ossowski, Michał Hułas, Rangvald Kallenberg, social role of researcher

The main target of this article is presentation of new trend in sociological discourse, which is public sociology. It was invented by american researcher Michael Burawoy. Since first announcement of his theses about role of sociology and the people who pracising it in modern society, public sociology became very prominent and face with extreme different opinions. While some people were treating it as new doctrine for social researchers, the others says that this trend hasn't any real value. One of main opponents of this approach in Poland is Piotr Sztompka. Next part of this article is devoted to his criticism of public sociology. Also there are quoted some other arguments expressed by oponents of Burawoy. The summary of this text is personal opionion of author concerned on public sociology and role of sociologist in nowadays society. 
Rozwój socjologii jako nauki był zawsze nierozerwalnie spleciony ze zmianami, jakim podlegał przedmiot jej badań, czyli samo społeczeństwo. Zależność tę dostrzegał między innymi Stanisław Ossowski. Pisał o tym w ten sposób:

Dzieje socjologii i socjologicznej postawy względem świata wiążą się ściśle z dziejami przemian społecznych. «Socjologiczny» relatywizm Montaigne'a w XVII wieku pozostaje w wyraźnej korelacji z przeobrażeniami kultury europejskiej w okresie renesansu, wielkich odkryć geograficznych. Koncepcja socjologii jako odrębnej nauki o społeczeństwie, nieutożsamianym już z organizacją państwową, rodzi się we Francji po Wielkiej Rewolucji, która przekształciła społeczeństwo stanowe w nowoczesne klasowe społeczeństwo. Związek socjologicznych teorii i socjograficznych badań Marksa i Engelsa ze skutkami rewolucji przemysłowej i kształtowaniem się nowoczesnego proletariatu nie budzi, jak się zdaje, niczyich wątpliwości. Początki socjologii amerykańskiej mają za tło gwałtowną urbanizację Ameryki po Wojnie Cywilnej, intensywne procesy imigracji, zamknięcie dziejów Zachodniej Granicy i wielkich obszarów ziemi niczyjej, mają za tło przekształcanie się kraju farmerów w kraj wielkiego przemysłu (Ossowski 1956b: 2).

W przytoczonej wypowiedzi opisany został w zarysie wpływ zmian społecznych na powstanie socjologii jako obszaru badań i wyodrębnionej organizacyjnie dyscypliny akademickiej. Pojawia się też rozróżnienie na socjologię jako naukę oraz socjologiczną postawę. O ile znaczenie pierwszego z tych terminów wydaje się jasne, o tyle drugi budzi już pewne wątpliwości. Można rozumieć go jako specyficzne nastawienie badacza społecznego do otaczającego świata oraz wolę poprawy jego stanu bądź to w drodze reform, bądź też przez rewolucję. Najlepiej chyba naturę postawy socjologicznej wyraża słynna teza Karola Marksa mówiąca, że filozofowie rozmaicie tylko interpretowali świat; idzie jednak o to, aby go zmienić (Marks 1975: 5-8).

Do takiego sposobu myślenia odwołuje się między innymi amerykański socjolog Michael Burawoy, propagujący ideę tak zwanej socjologii publicznej. W swoim artykule, który ukazał się w 2005 roku na łamach „American Sociological Review”, sformułował jedenaście tez dotyczących aktualnej kondycji socjologii jako nauki. Porównuje w nim socjologię do anioła historii, o którym w jednej ze swoich książek pisał Walter Benjamin (1996). Stoi on odwrócony plecami do przyszłości, twarzą zaś zwrócony jest ku przeszłości, która jawi mu się jako sterta ruin i niekończąca się katastrofa. Chciałby naprawić nieład, który znajduje się przed jego obliczem i nadać mu większy sens, jednak odpycha go od tego silny wicher. Tym wichrem ma być według Benjamina postęp społeczny.

Burawoy uważa, że dla pierwszych socjologów teoria społeczna była właśnie takim aniołem historii. Jej podstawowym celem było zracjonalizowanie świata i uczynienie go bardziej ludzkim. Pisze o tym w ten sposób:

W swych początkach socjologia dążyła do tego, by stać się takim właśnie aniołem historii, szukając ładu we fragmentach nowoczesności, próbując ocalić obietnicę postępu. I tak, Karol Marks wyzwolił socjalizm z alienacji; Emile Durkheim oswobodził solidarność 
organiczną z anomii i egoizmu; Max Weber, mimo przeczuwanej przez niego "mrożącej ciemności nocy polarnej", potrafił dostrzec obietnicę wolności w postępującej racjonalizacji i wydobyć znaczenie z procesu odczarowywania świata (Burawoy 2009: 526).

Socjologia w początkach swojego istnienia nie osiągała jednak zakładanych rezultatów. Burawoy zauważa, że choć pierwsi socjologowie wyruszali w swą intelektualną podróż po to, by zmienić świat, zbyt często kończyli na konserwowaniu go (2009: 526). Po początkowym okresie bardzo silnego zaangażowania się w zmiany społeczne badacze wycofali się do gabinetów oraz sal wykładowych i skupili na pracy ściśle analitycznej. Rozpoczęto budowanie skomplikowanych systemów teoretycznych i całych paradygmatów w oderwaniu od społecznego praxis. Socjologia, mówiąc językiem Marksa, wyalienowała się od swojego przedmiotu, czyli samego społeczeństwa. Przykładem mogą tu być abstrakcyjne systemy stworzone przez Roberta Mertona czy też Talcotta Parsonsa. Jak pisze Burawoy,

Poświęciliśmy cały wiek na budowanie wiedzy akademickiej, przekuwanie zdroworozsądkowych przeświadczeń w kategorie naukowe, i dlatego jesteśmy teraz gotowi rozpocząć systematyczną translację zwrotną, przekazywać wypracowaną przez nas wiedzę tym, od których ona pochodzi, wydobywając kwestie publiczne z ich prywatnych problemów, tym samym regenerując moralną tkankę socjologii (2009: 527).

Burawoy w ramach całej teorii socjologicznej wyróżnia cztery działy. Są to socjologia akademicka (professional sociology), praktyczna (policy sociology), krytyczna (critical sociology) oraz publiczna (public sociology). Każda z nich jest pewnym specyficznym spojrzeniem na socjologię, na jej cele i metody. To orientacja na pewne rodzaje wiedzy i sposoby jej legitymizacji; to socjologia skierowana do określonych osób jak to określa Burawoy - do określonej publiczności (Quo vadis, socjologio?..., 2007). Maciej Hułas uważa, że dla działów wymienionych przez Burawoya kluczowe są dwa pytania:

1. Czy socjologia powinna się koncentrować wyłącznie na technicznej analizie procesów społecznych i na ich racjonalnym wymiarze, czy też jej zadaniem jest ujmować procesy te w perspektywie teleologicznej, co oznacza, że dopuści pytania o wartości społeczne? 2. Czy adresatem dyskursu socjologicznego ma być wyłącznie środowisko akademii, czy może należy eskalować dyskurs socjologiczny również na środowiska pozaakademickie? (Hułas 2011: 35).

Odpowiedzi na każde z tych pytań stanowią linie podziału między wymienionymi subdyscyplinami socjologii.

Początki socjologii akademickiej sięgają XIX wieku i łączą się z dokonaniami takich myślicieli jak Auguste Comte, Herbert Spencer czy Emile Durkheim. Opiera się ona na standardowej metodologii naukowej, sprawdzonych procedurach i obiektywnych rezultatach badań. Sprawdzianem jej wartości jest koherencja formułowanych 
twierdzeń z konkretnymi fenomenami społecznymi. Socjologię akademicką uprawia się wyłącznie w ramach specjalistycznych jednostek badawczych - uniwersytetów czy instytutów naukowych. Jej głównymi celami jest produkcja sprawdzonej empirycznie wiedzy i kształcenie kolejnych adeptów tej dyscypliny. Ma odkrywać kolejne prawa i formułować tezy o zachodzących procesach społecznych. Socjologia akademicka jest zarazem fundamentem teoretycznym dla pozostałych działów socjologii. Jak pisze o tym sam Burawoy,

To ona w szczególności dostarcza pozostałym trzem komponentom legitymizacji i wiedzy eksperckiej. Z drugiej strony, to ona definiuje cały projekt socjologii jako taki, który nierozerwalnie związany jest ze społeczeństwem obywatelskim (Burawoy 2011: 199).

Odwołując się do teorii Pierre'a Bourdieu, można powiedzieć, że socjologia akademicka należy do pola nauki. Głównym zagrożeniem dla socjologii akademickiej jest samocytowanie się, czyli zamknięcie się w hermetycznym świecie monografii, punktowanych czasopism naukowych i prac dyplomowych w kompletnym oderwaniu od prawdziwych problemów społecznych.

Socjologia praktyczna ma zasadniczo odmienny charakter od socjologii akademickiej. Jest ona skupiona wyłącznie na empirycznym konkrecie. Nie zajmuje się budowaniem uniwersalnych tez o społeczeństwie, formułowaniu praw jego działania czy tworzeniu zaawansowanych systemów teoretycznych. Celem socjologii praktycznej jest badanie konkretnych grup społecznych dla celów pragmatycznych. Adresatem rezultatów tych badań są podmioty, dla których ważny jest wyłącznie instrumentalny aspekt wiedzy socjologicznej. Jak zauważa Hułas,

Socjologia praktyczna działa zatem na zlecenie konkretnego klienta zainteresowanego uzyskaniem profesjonalnej ekspertyzy na temat preferencji, nastrojów i postaw społeczeństwa. Wyjście poza środowisko akademii następuje wyłącznie w celu zdobycia informacji, które traktuje instrumentalnie, jako obiekt analiz użytecznych z punktu widzenia strategii rynkowej lub politycznej (Hułas 2011: 39).

To socjologia, z której rezultatami działań najczęściej ma do czynienia zwykły przeciętny obywatel, czasem nie zdając sobie zupełnie z tego sprawy (Quo vadis, socjologio?..., 2007). Głównym zagrożeniem dla socjologii praktycznej jest serwilizm i uleganie naciskom mocodawców. Ze względu na to, że jest skupiona wyłącznie na celach utylitarnych, może stać się narzędziem w rękach zleceniodawców, dla których nie mają znaczenia procedury badawcze, lecz wyłącznie rezultaty.

Z socjologią akademicką związana jest też socjologia krytyczna. Jest ona wewnętrzną refleksją nad funkcjonowaniem badań socjologicznych w ramach instytucji badawczych. Stawia sobie pytania o to, jakim w ogóle rodzajem nauki jest socjologia (to znaczy, czy jest bliższa humanistyce, czy też naukom ścisłym), jaka jest jej aktualna kondycja, jakie cele sobie powinna stawiać, w jaki sposób te cele osiągać i tym 
podobne. Socjologia krytyczna jest też namysłem nad metodologią badań społecznych. Zadaje pytanie o sprawdzalność tez socjologicznych, warunki ich prawdziwości i aplikowalności w praktyce. Zajmuje się rygoryzmem metodologicznym, a adresatem i adwersarzem prowadzonego przez nią dyskursu są krytyczni intelektualiści, będący w stanie zmieniać i określać nowe granice metodologiczne w socjologii (Hułas 2011: 40). Poza tym socjologia krytyczna koncentruje się na roli całego uniwersytetu w życiu publicznym. Burawoy w jednym z wywiadów stwierdza, że socjologie w wersji akademickiej oraz praktycznej są obecnie dominujące, dlatego też trzeba wzmocnić rolę socjologii krytycznej. Mówi o tym w ten sposób:

Obecnie wygląda na to, że funkcja akademicka i policy mają zdecydowaną przewagę nad pozostałymi. Obie jednak są skutecznie przejmowane przez dyskursy głównego nurtu - akademicka została poddana regulacji, a stosowana - komercjalizacji. Dlatego musimy wzmocnić krytyczną oraz publiczną funkcję uniwersytetu. W ramach funkcji krytycznej powinniśmy przeprowadzić dyskusję na uniwersytecie i w szerszej społeczności o tym, czym właściwie jest uniwersytet (Szołucha 2013: 81).

Ze względu na skupienie się na zasadach metodologicznych i procedurach badawczych socjologii krytycznej zagrażać może dogmatyzm.

Najważniejsza, ale i zarazem najbardziej kontrowersyjna w podziale Burawoya jest socjologia publiczna. Czym ona jest? Oto, jak wyjaśnia to sam autor tej koncepcji w jednej z tez przywoływanego wcześniej artykułu:

Co będziemy rozumieć przez socjologię publiczną? Socjologia publiczna skłania socjologię do rozmowy z publicznością, czyli ludźmi, którzy sami zaangażowani są w rozmowę. Zakłada więc ona podwójność rozmowy (double conversation) (Burawoy 2009: 530).

Tak można określić istotę tej części dociekań socjologicznych. Socjologia publiczna ma wdać się w dialog z grupami i jednostkami, które były przedmiotem jej badań. Powinna być też rozumiana bardziej jako styl uprawiania badań socjologicznych niż specyficzna metoda, teoria czy zbiór wartości politycznych (zob. Public sociology [2016]).

Socjologia publiczna skupia się przede wszystkim na kontakcie z grupami mniejszościowymi i marginalizowanymi. Celem tego kontaktu jest emancypacja tych grup i nadanie im podmiotowości. Socjolog dzięki wiedzy, którą zawdzięcza socjologii akademickiej oraz praktycznej, ma zmieniać warunki życia takich grup na lepsze. Jednak podmioty, $z$ którymi wdaje się $w$ interakcję, nie są zupełnie bierne, ale razem z nim działają dla realizacji wspólnego celu. Oto, jak dialogiczny charakter socjologii publicznej opisuje Hułas:

Formą uprawiania socjologii publicznej jest dialog, debata publiczna. Dialog socjologii z grupami społecznościowymi uzasadnia ich istnienie. Ponieważ dialog i debata informują o problemach, potrzebach i oczekiwaniach społecznych, stanowią źródło wiedzy dla 
socjologii publicznej, a wiedza ta ma charakter refleksyjny i komunikatywny. Konsensus, jaki generalnie socjologia osiąga w dialogu ze sferą publiczną, jest źródłem wiedzy, z której czerpie socjologia publiczna, i podstawą formułowanych przez nią sądów (Hułas 2011: 41).

Kolejną istotną kwestią odnośnie socjologii publicznych jest ich wielość. W przywoływanym już tekście Burawoya mówi o tym teza druga:

Istnieje wiele socjologii publicznych, odzwierciedlających różne typy publiczności i różne sposoby komunikowania się z nimi. Tradycyjne i organiczne socjologie publiczne są dwoma przeciwstawnymi i jednocześnie uzupełniającymi się typami socjologii publicznej. Publiczności mogą zostać zniszczone, ale i wykreowane. Niektóre z nich nigdy nie znikają nasi studenci są pierwszą skazaną na nas publicznością (Burawoy 2009: 530).

Konsekwencją współpracy socjologa z wieloma gremiami podczas prowadzenia badania i stosowania ich wyników w sposób, jaki sugeruje Burawoy, jest fakt, że wytwarza tak naprawdę wiele różnych socjologii publicznych. W każdej grupie badawczej zbierze inny materiał empiryczny, będzie miał inne cele badawcze oraz zastosuje inne metody. Każda z grup będzie też miała wobec socjologa inne oczekiwania. To zasadnicza różnica w stosunku do socjologii w wydaniu akademickim czy krytycznym. Akcent postawiony jest na działanie, a nie na osiągnięcie konkretnych rezultatów poznawczych.

W przytoczonej wyżej tezie drugiej pojawiają się terminy "tradycyjna socjologia publiczna” oraz "organiczna socjologia publiczna”. Należy w tym miejscu wyjaśnić ich znaczenie. Tradycyjna socjologia publiczna ma pełnić rolę podobną do tej, jaką przypisywali tej nauce jej twórcy. Socjolog w ten sposób zorientowany pracuje z grupami o niskim poziomie integracji i organizacji wewnętrznej. Nie są one świadome swoich potrzeb ani celów. Jak zauważa Burawoy, publiczności, do których odnosi się tradycyjna socjologia publiczna, są zazwyczaj niewidzialne - nierozpoznawalne, rzadkie nie wytwarzają intensywnych interakcji wewnętrznych, pasywne - nie konstytuują określonego ruchu społecznego czy organizacji i zazwyczaj wchodzą w główny nurt społeczeństwa (2009: 530). Relacja między badaczem a przedmiotem jego analiz ma charakter asymetryczny. To on - jako przedstawiciel świata akademickiego - posiada wiedzę fachową, natomiast grupa, z którą ma pracować, ze względu na swoją marginalizację w społeczeństwie nie jest świadoma swojej realnej pozycji społecznej. Tę asymetryczność zauważa też Hułas. Według niego tradycyjnej socjologii publicznej towarzyszy przeświadczenie, że społeczności ulegają fałszywej świadomości, która sprawia, że nie są w stanie rozumieć własnego położenia, zależności od innych sfer i czynników oraz przyczyn prowadzących do sytuacji zależności, w jakiej się znajdują (Hułas 2011: 42).

Burawoy odrzuca tradycyjny model uprawiania socjologii publicznej i uważa, że właściwą socjologią publiczną jest jej wersja organiczna. Ona to właśnie opiera się na dialogu i równości między badaczem a grupą badaną, której pozycję społeczną 
ten pierwszy stara się poprawić. Obie strony tego dialogu uczą się od siebie nawzajem. W ramach organicznej socjologii publicznej socjologowie pracują w bliskiej relacji z widoczną, gęstą, aktywną, lokalną i często stojącą w opozycji wobec głównego nurtu społeczeństwa publicznością (Burawoy 2009: 530). W organicznej socjologii publicznej zakłada się, że społeczności jako partner dialogu są świadome tego, że w relacji do państwa i do ekonomii znajdują się w pozycji podporządkowanego oraz że rozumieją przyczyny i warunki tego podporządkowania (Hułas 2011: 43). Michael Burawoy podkreśla również, że socjologia publiczna w wersji organicznej musi stać się integralną częścią działalności zawodowej socjologa. Aby nauka ta mogła spełnić postulaty, jakie postawili jej twórcy, musi wdać się w rozmowę z ludźmi, których bada i na których rzecz działa. Burawoy ujmuje to w ten sposób:

Musimy uznać tę organiczną socjologię, która często pozostaje niewidoczna, prywatna i znajduje się niejako na marginesie naszej zawodowej działalności, za część socjologii publicznej. Projekt takich socjologii publicznych zakłada bowiem uwidocznienie tego, co niewidoczne, uczynienie tego, co prywatne - publicznym, rozpoznanie i dowartościowanie tych organicznych koneksji jako części naszego socjologicznego życia (Burawoy 2009: 530).

Ważne jest również w proponowanym przez Burawoya systemie podziału wiedzy i pracy socjologicznej opisanie zależności, które łączą ze sobą wszystkie cztery wymienione subpola socjologiczne. Omawiany autor wyróżnia w tym celu dwa rodzaje wiedzy - instrumentalną oraz refleksyjną. Wiedza instrumentalna służy albo rozwiązywaniu problemów badawczych w ramach socjologii akademickiej, albo rozwikłaniu problemów przez socjologię praktyczną (2009: 535-536). Ma ona więc charakter stricte techniczny. Z kolei wiedza refleksyjna według Burawoya jest

zorientowana na dialog na temat celów, niezależnie od tego, czy dialog ten odbywa się wewnątrz społeczności akademickiej i dotyczy założeń programów badawczych, czy też między akademikami a zróżnicowanymi publicznościami, debatującymi nad kierunkiem rozwoju społeczeństwa. Wiedza refleksyjna bada przesłanki dotyczące wartości w obrębie społeczeństwa, ale i w ramach naszej dziedziny (2009: 536).

Zarówno wiedza instrumentalna, jak też refleksyjna mogą być skierowane do publiczności akademickiej i pozaakademickiej. Stosując te kryteria, można powiedzieć, że wiedza instrumentalna skierowana do gremium akademickiego odpowiada socjologii akademickiej, natomiast skierowana do ludzi spoza akademii odpowiada socjologii praktycznej. Z kolei wiedza refleksyjna, której adresatami są osoby ze świata nauki, mieści się w zakresie socjologii krytycznej. Kiedy ta sama wiedza jest skierowana do publiczności pozaakademickiej, zastosowanie znajdzie socjologia publiczna.

Ragnvald Kalleberg, analizując te podziały w ramach socjologii, które proponuje Burawoy, stwierdza, iż jego głównym problemem w sprawie dyskusji wokół socjologii publicznej jest to, że trudno odróżnić ją od konsultacji społecznych (czyli socjologii praktycznej), instytucjonalnego zarządzania i studiów akademickich (Kalleberg 2005: 
389). Autor ten przypomina też tezę Burawoya o tym, że głównym zadaniem socjologii publicznej w jej wydaniu organicznym jest współpraca z różnymi grupami społecznymi, takimi jak ruchy pracownicze, wspólnoty religijne, różnego rodzaju mniejszości i tym podobne. Jednak uważa, że w tym zakresie pole socjologii publicznej pokrywa się z innymi subpolami socjologii. Ujmuje to w następujący sposób:

To brzmi jak socjologia praktyczna (gdy socjolog występuje jako ekspert). Uważam, że w większości tych projektów socjologowie biorą udział przede wszystkim jako wykwalifikowani fachowcy, których celem jest poprawa sytuacji grup, które są ich klientami. Ponadto sądzę, że część tej pracy powinna być klasyfikowana jako aktywność polityczna, doskonale legitymowana przez autorytet nauki, ale de facto poza jej granicami (2005: 389-390).

Opinia Kalleberga dotycząca pewnych mankamentów i nieścisłości w ramach koncepcji socjologii publicznej prowadzi nas ku krytyce tego podejścia badawczego. Jednym z oponentów koncepcji Burawoya jest Piotr Sztompka. Zauważa on, że współcześnie rozwojowi socjologii zagrażają dwa zjawiska. Pierwsze to postmodernizm głoszący niemożliwość naukowego badania społeczeństwa ze względu na jego rzekomą fragmentaryczność, atomizację, płynność, przypadkowość zmian (Sztompka 2012: 7). Przykładem jest tu chociażby dorobek naukowy Zygmunta Baumana. Natomiast drugie zagrożenie to lewacki aktywizm przynoszący ideologizację i polityzację socjologii, wzywający do akcji rewolucyjnej, a nie do myślenia, przemawiający do emocji, a nie do rozumu, prowadzący socjologów na barykady zamiast do bibliotek (2012: 7). Głównym powodem tego drugiego zagrożenia jest - według Sztompki - właśnie projekt socjologii publicznej, której twórcą i najważniejszym propagatorem jest Burawoy.

W artykule, który ma stanowić zasadniczą część polemiki z Burawoyem, Sztompka ujmuje zarzuty pod adresem socjologii publicznej i jej twórcy w postaci dziesięciu tez. Jest to analogia do konstrukcji artykułu, w którym Burawoy proklamuje powstanie socjologii publicznej. Pierwsze cztery tezy opisują ogólnie naturę prowadzenia badań społecznych w ujęciu Sztompki, natomiast pozostałe sześć wiąże się stricte z koncepcją Burawoya. Teza piąta głosi, że drogowskazem ambicji poznawczych socjologii, ostatecznym, choć nigdy do końca nieosiągalnym celem, jest wyjaśniający model ludzkich działań, praktyk i relacji międzyludzkich, czyli ogólna teoria społeczeństwa (Sztompka 2012: 10). Polski badacz odnosi się tu do postulatu Burawoya, jakoby celem socjologii miała być nie teoria społeczna jako wartość autoteliczna, lecz jako narzędzie służące emancypacji grup dyskryminowanych. Z kolei teza szósta mówi, że ogólność wyników badawczych socjologii oznacza także ich uniwersalność, a najogólniejsze prawidłowości socjologii stosują się po prostu do ludzi jako ludzi (2012: 11). Jest więc to atak skierowany wobec tezy Burawoya, która głosi, że istnieje wielość socjologii publicznych. Sztompka uważa, że rezultatem badań socjologicznych ma być ogólna teoria społeczeństwa odnosząca się do ludzi jako takich. 
Natomiast tezy od siódmej do dziesiątej, choć dystansują się od koncepcji Burawoya, to jednak w pewien sposób z nim korespondują. Sztompka zwraca w nich uwagę, że wyniki badań socjologicznych nie powinny być zbyt oddalone od ludzi i ich codziennych spraw. Co więcej, mają poprawiać jakość codziennego życia. Adresatem badań socjologicznych są nie tylko zawodowi socjologowie, ale również podmioty spoza pola akademickiego. To zbliża podejście Sztompki do dialogicznego podejścia w badaniach społecznych, które proponuje Burawoy. Poza tym Sztompka uważa, że socjolog może sobie pozwolić na wartościowanie, ale wyłącznie przy wyborze przedmiotu analiz oraz po przeprowadzeniu badań i komentowaniu ich wyników. Poza tym socjologowie powinni wdawać się też w dialog z przedstawicielami innych dziedzin naukowych.

Warto też zauważyć, że Piotr Sztompka określa działalność amerykańskiego teoretyka mianem leninizmu (Sztompka 2013). To dość silny atak, zważywszy na fakt, że Lenin w potocznej świadomości jest traktowany przede wszystkim jako jeden z głównych ideologów komunizmu, który - jako ustrój totalitarny - jest powszechnie potępiany. Aby jednak przeanalizować głębiej tę kwestię, warto przytoczyć cytat z artykułu, który stanowi refleksję nad statusem Lenina jako teoretyka społeczeństwa. Jak pisze Stanisław Kozyr-Kowalski,

Jeśli ktoś przyjmie biurokratyczno-instytucjonalną koncepcję nauki, która utożsamia status naukowy socjologii z jej statusem akademickim, dla której początkiem dziejów socjologii jest pojawienie się pierwszych katedr, książek i wykładów opatrzonych przydomkiem socjologii, wówczas obdarzenie Lenina mianem socjologa będzie stanowiło dla niego bluźniercze wyzwanie (Kozyr-Kowalski 1970: 61).

Zarzut Piotra Sztompki musi opierać się na milczącym przyjęciu takiej właśnie wizji nauki o społeczeństwie. W tym ujęciu określenie czyichś koncepcji mianem „leninizmu" stanowi de facto wyprowadzenie danej osoby poza obręb akademii.

Wspomniano już o kategorii pola naukowego stworzonej przez Pierre'a Bourdieu. Aby zrozumieć głębiej krytykę wysuwaną pod adresem socjologii publicznej przez Sztompkę, należałoby ponownie przytoczyć rozważania Bourdieu. W jednym z tekstów francuski naukowiec pisze:

Jako system stosunków obiektywnych między uzyskanymi pozycjami (dzięki uprzednim walkom) dziedzina naukowa jest polem (to znaczy przestrzenią gry) walki konkurencyjnej, która nastawiona jest na szczególną stawkę - monopol autorytetu naukowego, definiowanego równocześnie i jako umiejętność techniczna, i jako władza społeczna lub - jeśli kto woli - monopol kompetencji naukowej rozumianej jako zdolność mówienia i działania w sposób uprawomocniony (to znaczy w sposób autorytatywny i z autorytetem) w nauce, która jest społecznie przypisana określonemu aktorowi (Bourdieu 1984: 87).

W perspektywie przytoczonej wypowiedzi Bourdieu krytyka Sztompki wyartykułowana wobec Burawoya jawi się jako walka konkurencyjna w polu naukowym, która 
wynika de facto z dwóch różnych wizji naukowości socjologii. O ile polskiego badacza można uznać za wyznawcę koncepcji neutralności politycznej i ideologicznej socjologii, o tyle Burawoy staje na stanowisku, zgodnie z którym socjolog powinien być silnie zaangażowany w aktualne problemy. Stawką w tym sporze jest, odwołując się ponownie do wypowiedzi Bourdieu, monopol autorytetu naukowego i związany z tym prestiż w swojej dziedzinie.

Po przeprowadzeniu analizy argumentów za i przeciw socjologii publicznej pojawia się ogólne pytanie o to, jaką rolę może i powinien pełnić socjolog w społeczeństwie. Jest on nie tylko zewnętrznym obserwatorem rzeczywistości społecznej, ale również jej uczestnikiem, który w ograniczony sposób decyduje o jej kształcie. Z tego względu często znajduje się on w sytuacji, kiedy chciałby zaangażować się w realne rozwiązywanie danego problemu społecznego. Aby móc to zrobić poprawnie, trzeba jednak posiadać absolutnie pewną wiedzę dotyczącą funkcjonowania społeczeństwa albo przynajmniej jego wybranej sfery. Jak pisze Florian Znaniecki,

Ażeby skutecznie rozwiązać jakiś problem praktyczny, działacz potrzebuje obiektywnej wiedzy o zjawiskach, które usiłuje zmodyfikować. W czasach współczesnych wiedza taka opiera się głównie na osiągnięciach nauk teoretycznych. W przypadku problemów społecznych zasadnicze znaczenie ma niewątpliwie wiedza socjologiczna, choć potrzebna może być również wiedza z innych dziedzin (np. ekonomiki i psychologii) (Znaniecki 1984: 496).

Aktualnie socjologia nie może pochwalić się zbyt dużym zbiorem tego typu wiedzy. Co prawda, istnieją nieliczne prawa stwierdzone przez socjologów, do których zaliczyć możemy przykładowo żelazne prawo oligarchii Michelsa, teorię krążenia elit Pareta czy mechanizm dwustopniowego procesu przebiegu opinii publicznej opracowany przez Lazarsfelda, jednak nie są to teorie, na które zgodzi się każdy bez wyjątku. Z tego też względu badacz, który chciałby rzucić się w wir zdarzeń społecznych w celu ich pozytywnej modyfikacji, może narazić się na zarzut leninizmu, który wyartykułował Sztompka pod adresem Burawoya.

Być może najlepszą rolą dla socjologa w praktyce byłaby rola krytyka. Łączyłaby ona w sobie cele, jakie Burawoy stawiał przed socjologią praktyczną oraz krytyczną, przy zachowaniu autorytetu socjologii akademickiej. Opisywana na początku tej pracy postawa socjologiczna zakłada pewien rodzaj niepokorności w działalności intelektualnej i społecznej. I takie też przymioty powinien posiadać socjolog, działając wśród ludzi. Warto tu ponownie odwołać się do Stanisława Ossowskiego, który ujął to bardzo trafnie. Według niego

Pracownik naukowy to taki człowiek, do którego zawodowych obowiązków należy brak posłuszeństwa w myśleniu. Na tym polega jego służba społeczna, aby pełniąc swe zawodowe czynności, nie był w myśleniu posłuszny. Pod tym względem nie wolno mu być posłusznym ani synodowi, ani komitetowi, ani ministrowi, ani cesarzowi, ani Panu Bogu. Jeżeli jest posłuszny, jeżeli poglądy swoje zmienia na rozkaz, albo jeżeli myśl jego nie jest 
w zgodzie z jego słowami, sprzeniewierza się swoim obowiązkom, tak jak się sprzeniewierza inżynier, który dla świętego spokoju, albo dla zysku, albo przez lenistwo, albo przez małoduszność pustakami zastępuje żelazobeton albo drewnem granit (Ossowski 1956a: 4).

Socjologia ma obecnie narzędzia pozwalające jej diagnozować różne zjawiska społeczne i porównywać je ze stanem pożądanym. Może więc taki sposób zaangażowania socjologa w społeczne praxis wydaje się być najbardziej zasadny.

\section{Literatura}

Benjamin W., 1996, Anioł historii. Eseje, szkice, fragmenty, wyb., oprac. H. Orłowski, tłum. K. Krzemieniowa, H. Orłowski, J. Sikorski, Poznań: Wydawnictwo Poznańskie.

Bourdieu P., 1984, Specyfika dziedziny naukowej i społeczne warunki rozwoju wiedzy, tłum. E. Neyman [w:] Kryzys i schizma. Antyscjentystyczne tendencje w socjologii współczesnej, t. 2, wyb., wstęp E. Mokrzycki, Warszawa: PIW.

Burawoy M., 2009, O socjologię publiczną. Przemówienie prezydenckie z roku 2004, tłum. A. Dziuban [w:] Nowe perspektywy teorii socjologicznej. Wybór tekstów, red. A. Manterys, J. Mucha, współpr. M. Kaczmarczyk, Kraków: Nomos.

Burawoy M., 2011, Krytyczny zwrot ku socjologii obywatelskiej, tłum. K. Mikołajewska, „Stan Rzeczy”, nr 1.

Hułas M., 2011, Public sociology jako nowa subdyscyplina naukowa według Michaela Burawoya, „Roczniki Nauk Społecznych", t. 3.

Kalleberg R., 2005, What Is „Public Sociology"? Why and How Should It Be Made Stronger?, "The British Journal of Sociology", Vol. 56, Iss. 3.

Kozyr-Kowalski S., 1970, Lenin - socjolog nie odkryty w pełni (o sposobach badania socjologii leninowskiej), "Studia Socjologiczne", nr 4.

Marks K., 1975, Tezy o Feuerbachu, tłum. S. Filmus [w:] K. Marks, F. Engels, Dzieła, t. 3, Warszawa: Książka i Wiedza.

Ossowski S., 1956a, Taktyka i kultura, „Przegląd Kulturalny”, nr 13.

Ossowski S., 1956b, O socjologii i przeobrażeniach współczesnego świata, „Przegląd Kulturalny”, nr 40.

Public sociology, [2016], Wikipedia, https://en.wikipedia.org/wiki/Public_sociology [dostęp: 9.06.2016].

Quo vadis, socjologio? O public sociology Michaela Burawoya, 2007, Socjoszpieg, http://socjoszpieg. blox.pl/2007/07/Quo-vadis-socjologio-O-public-sociology-Michaela.html [dostęp: 9.06.2016].

Szołucha A., 2013, Uniwersytet w kryzysie. Z M. Burawoyem rozmawia A. Szołucha, „Praktyka Teoretyczna", nr 1.

Sztompka P., 2012, Dziesięć tez o socjologii, „Nauka”, nr 4.

Sztompka P., 2013, Kolejna socjologiczna utopia, Katolicki Uniwersytet Lubelski Jana Pawła II, http://pracownik.kul.pl/files/37099/public/Sztompka_Kolejna_socjologiczna_utopia.pdf [dostęp: 9.06.2016].

Znaniecki F., 1984, Społeczne role uczonych, wyb., wstęp, tłum. red. J. Szacki, Warszawa: PWN. 